\title{
The Furongian (late Cambrian) Steptoean Positive Carbon Isotope Excursion (SPICE) in Avalonia
}

\author{
Mark A. Woods ${ }^{1 *}$, Philip R. Wilby ${ }^{1}$, Melanie J. Leng ${ }^{2}$, Adrian W. A. Rushton ${ }^{1}{ }^{3}$ \\ \& Mark Williams ${ }^{1,4}$ \\ 1: British Geological Survey, Keyworth, Nottingham, NG12 5GG, UK \\ 2: NERC Isotope Geosciences Laboratory, British Geological Survey, Keyworth, \\ Nottingham, NG12 5GG, UK \\ 3: Department of Palaeontology, The Natural History Museum, Cromwell Road, \\ South Kensington, London, SW7 5DB, UK \\ 4: Department of Geology, University of Leicester, Leicester LE1 7RH, UK \\ ${ }^{\star}$ Corresponding author Mark Woods (email: maw@bgs.ac.uk)
}

The Steptoean Positive Carbon Isotope Excursion (SPICE) of earliest late Cambrian (Furongian) age is identified in England. The excursion is found within a ca $145 \mathrm{~m}$ thick siliciclastic succession within the middle and higher part of the Outwoods Shale Formation of Warwickshire, and reaches a maximum $\delta^{13} \mathrm{C}_{\text {org }}$ amplitude of $4.1 \%$ at values of $-25.6 \%$. Biostratigraphical data show that the excursion occupies the greater part of the Olenus trilobite biozone, an equivalent of the Glyptagnostus reticulatus biozone that marks the base of the Furongian and coeval base of the Steptoean in North America. The amplitude of the excursion approaches that recorded in limestonedominated Laurentian successions, and is greater than that recently documented for organic-rich mudstones of palaeocontinental Baltica in southern Sweden. A minor positive excursion above the SPICE may equate with a similar excursion recognised in Siberia. The SPICE in the Outwoods Shale Formation seems closely linked to the widely recognised early Furongian eustatic sea level rise. There is no evidence in the English succession for slightly later regression, elsewhere considered coincident with the peak of the excursion and pivotal to some previous models explaining the SPICE.

Keywords: Cambrian, Furongian, carbon isotope excursion, England, Avalonia

Late Cambrian (Furongian) carbonate successions in many parts of the world (North America, Argentina, Siberia, Kazakhstan, China, Australia) contain an interval of markedly positive $\delta^{13} \mathrm{C}_{\text {carb }}$ values, peaking at $+5 \%$ (Saltzman et al., 2000; Kouchinsky et al., 2008). More recently, the same positive Carbon Isotope Excursion ( $\mathrm{CIE}$ ) has been identified in organic-rich mudstones of the Alum Shale Formation in southern Sweden, where $\delta^{13} \mathrm{C}_{\text {org }}$ peak values are around $-28 \%$ (with a maximum amplitude of around 2\%o) (Ahlberg et al., 2009). This CIE, first recognised in the late Cambrian of North America by Brasier (1993) and confirmed as a global CIE by Saltzman et al. (1995), is termed the Steptoean Positive Carbon Isotope Excursion (SPICE) (Saltzman et al., 1998). We report here the occurrence of the SPICE in the Cambrian of central England, the first record in an Avalonian succession. The palaeogeographic setting of these mid-shelf clastic deposits contrasts with 
areas where the SPICE has previously been identified (e.g. shallow carbonate shelf in North America; shallow, dysoxic-anoxic shelf in southern Sweden). This contrasting setting provides an opportunity to critically assess the likely driving mechanism(s) that created this global isotopic excursion.

The SPICE is believed to have had a duration of about $4 \mathrm{Ma}$ (Saltzman et al., 1998), although $3 \mathrm{Ma}$ is probably a better estimate based on dates recently published by Peng and Babcock (2008). In common with other positive CIEs in the geological record, one interpretation of the SPICE is attributed to increased burial of organic carbon, that is enriched in isotopically light ${ }^{12} \mathrm{C}$ thus increasing the ${ }^{13} \mathrm{C}$ pool in the oceans. However, terrestrial weathering impacts related to sea level and/or climate change have also been considered as explanations (Saltzman et al., 2000, 2004; Gill et al., 2007b).

A link between the SPICE and high organic carbon burial is suggested by data from Nevada that show the event to be associated with a positive sulphur isotope $\left(\delta^{34} \mathrm{~S}\right)$ excursion. This is interpreted to reflect large-scale diagenetic pyrite development and burial under reducing sedimentary conditions (Gill et al., 2007b). This relationship is less clear in western Newfoundland, where SPICE is not positively correlated with $\delta^{34} \mathrm{~S}$. It may show that the relationship of SPICE and $\delta^{34} \mathrm{~S}$ is significantly affected by local environmental restrictions, heterogeneity of $\delta^{34} S$ in Cambrian sea water, or ocean redox fluctuations (Hurtgen et al., 2009). There is also no evidence for widespread black shales coinciding with the positive $\mathrm{CIE}$, although these may have been restricted to deep ocean basins rather than the relatively shallow shelf margins that are inferred to be the depositional setting of most of the studied late Cambrian successions (Cramer \& Saltzman, 2007; Álvaro et al., 2008). An exception is the Alum Shale Formation of Sweden. Here, thick black shales formed across a broad, poorly oxygenated shelf of no great depth, and span a much greater interval of time than represented by the SPICE alone (perhaps $25 \mathrm{Ma}$ ) (Thickpenny, 1984,1987). Glumac and Walker (1998) and Saltzman et al. (1998) suggested that ocean stratification and black shale formation might have been widespread in the late Cambrian, with the SPICE representing a short-lived pulse of enhanced ${ }^{13} \mathrm{C}$ burial controlled by weathering or biological productivity. Cowan et al. (2003) suggested that very high sea-levels immediately prior to the SPICE could have fertilised the oceans through remobilising nutrients previously concentrated by protracted continental weathering of un-vegetated cratons. This nutrient pulse could have resulted in a surge of biological productivity, creating the SPICE.

Saltzman et al. $(2000,2004)$ discussed the potential role of globally enhanced weathering of isotopically heavy marine carbonates linked to a glacial event as a driver for the SPICE. Although supporting evidence for this appears to be provided by a purported widespread sea level fall (of about $25 \mathrm{~m}$; Saltzman et al., 2000) that coincides with the peak of the SPICE, there is no unambiguous evidence for a high latitude ice sheet in the late Cambrian (Saltzman et al., 2000). There are also geochemical data from Siberia suggesting that the SPICE broadly coincides with very high ${ }^{87} \mathrm{Sr} /{ }^{86} \mathrm{Sr}$ ratios in sea water, implying high rates of continental chemical weathering for the late Cambrian (Kouchinsky et al., 2008). Whilst enhanced chemical weathering may lead to 
global cooling through draw-down of atmospheric carbon dioxide, some data suggest that rates of chemical weathering are relatively low in modern-day cold environments (Raymo, 1991); perhaps the geochemical data are symptomatic of global greenhouse conditions during the SPICE. There is a further problem with the interpretation of relative sea level changes with respect to the SPICE. Although there appears to be a general consensus that the peak of the SPICE coincided with a global sea level lowstand, this scenario requires differing palaeoenvironmental interpretations for lithologically similar units; shale/wackestone-dominated sediments deposited at the onset of the SPICE in North America reflect drowning of the carbonate shelf, whilst similar lithofacies at the peak of the SPICE are believed to represent lowstand deposits, the latter based largely on the presence of an inferred coeval hiatus in trilobite faunas and missing $\delta^{13} \mathrm{C}$ SPICE in North American cratonic successions (Saltzman et al., 1998). Other evidence cited in favour of global late Cambrian regression includes carbonate platform exposure in Queensland and seamount-margin collapse in Kazakhstan (Cook et al., 1991; Saltzman et al., 2004).

Whatever theory is advanced to explain the SPICE, it needs to take account of strong circumstantial evidence for a link with changes of diversity in trilobite populations (Saltzman et al., 1998; Zhu et al., 2006). After an initial extinction event, at the onset of the SPICE, some studies have recorded a diversification of trilobite faunas through the overlying succession occupied by the excursion, with peak diversity coinciding with the peak of the excursion (Saltzman et al., 2000). An exception to this pattern occurs in shallow marine carbonates of the northwestern Siberian platform, where the mostly endemic trilobite fauna declines in diversity below the onset of SPICE, and continues to decline through the event (Kouchinsky et al., 2008).

With so many uncertainties remaining about the interpretation of the SPICE, its wider recognition in a variety of contrasting palaeogeographical and palaeoenvironmental settings appears to offer the best hope for future understanding.

\section{Geological setting}

In the late Cambrian, southern Britain occupied a high latitude (ca $60^{\circ}$ ) location in the southern hemisphere, on the south-east margin of the lapetus Ocean (Cocks \& Torsvik, 2002; Fig. 1). The region formed part of Eastern Avalonia, a small palaeocontinent that also comprised crustal fragments of North America, Belgium and Germany, that may have been attached to the western edge of Gondwana throughout the Cambrian (Brenchley et al., 2006), or which may have been separated from it (Landing \& MacGabhann, 2010). Within this broader framework, three main depositional settings can be recognised in the Cambrian of southern Britain: the Welsh Basin to the west, the Midland Platform covering central England, and a conjectural Anglian Basin to the east (Fig. 2). The Welsh succession is structurally complex and the Anglian succession unproven. In North Wales, Furongian (late Cambrian) rocks that are coeval with the SPICE are mainly represented by parts of the turbiditic Maentwrog and Ffestiniog Flags formations (Mawddach Group) 
(Allen \& Jackson, 1985; Pratt et al., 1995; Howells \& Smith, 1997; Young et al., 2002) or, locally, by the partial laterally equivalent Marchlyn Formation (Howells \& Smith; Howells, 2007); in South Wales they form part of the Lingula Flags Formation. These units comprise mudstones, siltstones and sandstones. Correlative Furongian mudstones are absent from Shropshire and poorly known at Malvern (Cowie et al., 1972; Rushton, 1999).

Across the Midland Platform, Furongian strata are relatively complete and undisturbed. The region formed a stable, but gently subsiding, intra-cratonic shelf (Bridge et al., 1998; Brenchley et al., 2006; Rushton et al., 1999), across which there was near-continuous deposition throughout most of the later Cambrian, and limited post-depositional deformation. This geological setting, combined with the availability of borehole material with comprehensive biostratigraphical data, make the succession of the Midland Platform the optimum area in the southern UK for investigation of the SPICE. The $950 \mathrm{~m}$ thick Cambrian succession partly crops out within a narrow, south-westward dipping inlier near Nuneaton, Warwickshire (Fig. 3), and consists of the sandrich early Cambrian Hartshill Sandstone Formation, overlain by the mudrockdominated Stockingford Shale Group, of mid Cambrian to earliest Ordovician age. Although marine depositional environments across the Midland Shelf are thought to have been relatively shallow throughout the Cambrian, the finergrained sediments of the Stockingford Shale Group probably represent comparatively deeper water conditions. The group comprises a number of mudstone formations, and a thin sandstone unit (Moor Wood Sandstone Formation; $15 \mathrm{~m}$ thick) of limited geographical development (Bridge et al., 1998). One of these mudstone units, named the Outwoods Shale Formation, is coeval with strata in North America recording the SPICE (Fig. 4).

The Outwoods Shale Formation comprises interbedded dark grey and pale grey mudstones, and rare, very thin (typically $25 \mathrm{~mm}$ ) sandstones with wavy or current bedding (Taylor \& Rushton, 1971, pp. 9 -22). Whilst deposition probably occurred under poorly oxygenated conditions, alternation of dark, pyritic mudstones with grey, burrowed mudstones suggests frequent fluctuation between relatively reducing and oxidizing marine environments (Taylor \& Rushton, 1971). This is consistent with high frequency fluctuations in total organic carbon (TOC) data obtained from the Outwoods Shale Formation during this study (Appendix 1) The Outwoods Shale Formation is intruded by spessartite lamprophyre sills (forming part of the Midlands Minor Intrusive Suite) dated as Late Ordovician (Bridge et al., 1998), making accurate assessment of the formation's true thickness problematic. Including intrusive rocks, Taylor and Rushton (1971) calculated it as about $300 \mathrm{~m}$ thick; Bridge et al. (1998) estimated it to be 250 m excluding the igneous rocks.

The fauna of the Outwoods Shale Formation includes 36 species of trilobite (+ agnostoids), indicating assignment to the Agnostus pisiformis, Olenus and Parabolina spinulosa biozones (Taylor \& Rushton, 1971; Rushton, 1978, 1983; Bridge et al., 1998; Fig. 4). The fauna includes cosmopolitan genera that Taylor and Rushton (1971) equated with the Dresbachian and lowest Franconian stages of North America; stages that equate with the Marjuman and Steptoean of Ludvigsen and Westrop (1985). 
In the late 1960s the British Geological Survey (BGS) drilled a number of boreholes in the Nuneaton area of Warwickshire, two of which penetrated the Outwoods Shale Formation (Fig. 3). Cores from these boreholes form the basis of the current investigation into the development of the SPICE in Avalonia. The base and lower part of the formation were proved by Merevale Borehole No. 3 [National Grid Reference SP 3071 9574; depth interval 0 $157.96 \mathrm{~m}]$, and the top and higher part of the formation were proved by Merevale Borehole No. 1 [SP 2994 9608; depth interval 130.28 - $217.63 \mathrm{~m}$ ] (Fig. 5). Between the base of Merevale No. 1 and the top of Merevale No. 3 there is an un-cored interval, approximately $50 \mathrm{~m}$ thick, which is represented in outcrops and was sampled at Oldbury Quarry [SP 310 950, 305 960].

\section{Material and methods}

Curated borehole material from the Outwoods Shale Formation in Merevale boreholes 1 and 3 includes bulk rock samples from every $1 \mathrm{ft}(\mathrm{ca} 0.3 \mathrm{~m})$ core interval. This material was sub-sampled for organic carbon isotope analysis $\left(\delta^{13} \mathrm{C}_{\text {org }}\right)$ at $1.22 \mathrm{~m}(4 \mathrm{ft})$ intervals, between $89 \mathrm{~m}(292 \mathrm{ft})$ and ca $1.8 \mathrm{~m}(6 \mathrm{ft})$ depth in Merevale Borehole 3, and $217.6 \mathrm{~m} \mathrm{(714} \mathrm{ft)} \mathrm{and} 130.75 \mathrm{~m} \mathrm{(429} \mathrm{ft)} \mathrm{in}$ Merevale Borehole 1. Based on an average dip of $26^{\circ}$ for the strata in Merevale 1 and $35^{\circ}$ for Merevale 3, the true vertical depth frequency for sampling of these boreholes is $1.09 \mathrm{~m}$ and $0.97 \mathrm{~m}$ respectively. Some irregularities in sample frequency result from small intervals of core loss or absence of bulk material for sampling at particular depths in the archived samples. The borehole sampling included intervals adjacent to igneous intrusions, so that the impact of these on isotopic values could be assessed.

The detailed biostratigraphy of the Merevale boreholes was described by Taylor \& Rushton (1971) and Rushton $(1978,1983)$. These Furongian trilobite faunas resemble coeval successions in Scandinavia, characterised by the olenid biofacies. This facies is generally considered to reflect poorly oxygenated marine environments, as also indicated by the presence of phosphatocopid arthropods (Williams et al. 1994; Williams \& Siveter, 1998). The interval we sampled ranges from the upper part of the Agnostus pisiformis Biozone, through the Olenus Biozone (= Glyptagnostus reticulatus Biozone of Terfelt et al., 2008), to the base of the Parabolina spinulosa Biozone, a biostratigraphical interval that spans strata coeval with the North American Steptoean succession (Fig. 4). Direct correlatives of the subzones in the lower part of the Scandinavian Olenus Biozone are recognisable in the Outwoods Shale Formation, the base of the zone being taken at the first appearance of Glyptagnostus reticulatus (Angelin) and Olenus gibbosus (Wahlenberg), at $55 \mathrm{~m}$ depth in Merevale Borehole 3. The latter differs from the usage of Rushton (1978), which was based on the appearance of Homagnostus obesus (Belt) at $61 \mathrm{~m}$ depth. The upper part of the Olenus Biozone, represented in the outcropping succession in Oldbury Quarry and in Merevale Borehole 1 (Fig. 5), was designated the O. cataractes Subzone by Rushton (1983), because the homotaxial Scandinavian subzones of $O$. attenuatus, $O$. dentatus and $O$. scanicus could not be recognised in detail. In Sweden, the presence of Irvingella major Ulrich \& Resser in the base of the $P$. 
spinulosa Biozone (Rushton \& Weidner, 2010) suggests that the top of the Steptoean and the top of the Olenus Biozone are practically coincident.

Supplementary bulk rock sampling was undertaken on the exposed succession at Oldbury Quarry [SP 30965 94922], covering the stratigraphical gap in the cored succession between the base of Merevale Borehole 1 and the top of Merevale Borehole 3 (drilled in the bottom of the quarry). Most of the outcrop sampling was at $1 \mathrm{~m}$ intervals (true vertical depth), and spans a total stratigraphical interval of ca $47 \mathrm{~m}$, including a $5 \mathrm{~m}$ thick igneous intrusion (Fig. 6). These samples also provided additional faunal data for the outcropping succession.

The samples were initially treated with $5 \%$ hydrochloric acid $(\mathrm{HCl})$ to remove any carbonate material. To achieve this, approximately $1 \mathrm{~g}$ of sample material was placed in a $500 \mathrm{ml}$ beaker and $100 \mathrm{ml}$ of $5 \% \mathrm{HCl}$ acid reagent added and left for 24 hours. Depending on the carbonate content additional acid was added to maintain an acidic solution. After 24 hours, the beaker was topped up to $500 \mathrm{ml}$ with deionised water and the sample material allowed to settle for a further 24 hours. Once settled, the supernatant was decanted, ensuring minimal disturbance of the sediment, and the beaker then topped up again to $500 \mathrm{ml}$ with deionised water. Dilution was repeated 3 times in total with an overall minimum of $1200 \mathrm{ml}$ of deionised water used. After the final decanting, the excess water $(50-100 \mathrm{ml})$ was allowed to evaporate off in a drying oven at $\sim 50^{\circ} \mathrm{C}$. Once dry, the sample was loosened from the base of the beaker with a clean plastic spatula and transferred to an agate pestle and mortar, ground, and a known quantity ( $500 \mu \mathrm{g} \mathrm{C})$ weighed into a tin capsule.

${ }^{13} \mathrm{C} /{ }^{12} \mathrm{C}$ analyses were performed using a Carlo Erba 1500 on-line to a VG TripleTrap (plus secondary cryogenic trap in the mass spectrometer for these very low carbon content samples) and Optima dual-inlet mass spectrometer, with $\delta^{13} \mathrm{C}$ values calculated to the VPDB scale using a within-run laboratory standard (BROC1) calibrated against NBS-19 and NBS-22. Replicate analysis of well-mixed samples indicated a precision of about $0.2 \%$ (1 SD).

\section{Analytical Results}

Figure 5 shows bulk rock $\delta^{13} \mathrm{C}_{\text {org }}$ for the sampled interval in Merevale boreholes 1 and 3 and the outcropping succession at Oldbury Quarry. A table of analytical results is given in Appendix 1, including total organic carbon (TOC) values for each sample.

$\delta^{13} \mathrm{C}_{\text {org }}$ shows the development of a broad positive CIE (Excursion1) within the Olenus Biozone of the Outwoods Shale Formation, with maximum amplitude of around $4.1 \%$. A smaller positive excursion (Excursion 2), with amplitude of about 1.1\%, occurs in the top of the Olenus Biozone and basal $P$. spinulosa Biozone. Excursion 1 occupies an estimated (dip corrected) composite stratigraphical thickness of about $145 \mathrm{~m}$, whilst Excursion 2 spans a $25 \mathrm{~m}$ thick interval. 
The base of Excursion 1 begins at around $54 \mathrm{~m}$ depth in Merevale Borehole 3 , approximately $7 \mathrm{~m}$ above the base of the Olenus Biozone, where there is a distinct inflection in $\delta^{13} \mathrm{C}_{\text {org }}$ and the start of an upward trend to more positive $\delta^{13} \mathrm{C}_{\text {org }}$. Values of $\delta^{13} \mathrm{C}_{\text {org }}$ peak at $-27.2 \%$ in the upper part of Merevale Borehole 3, increase further to $-25.6 \%$ in the outcrop succession at Oldbury Quarry (Figs 5,6 ), and then progressively decline to $-29.7 \%$ at the top of the excursion in the Merevale 1 succession, measured as occurring at approximately $174 \mathrm{~m}$ depth.

From $85 \mathrm{~m}$ to $54 \mathrm{~m}$ depth in Merevale Borehole 3, and between $162.5 \mathrm{~m}$ and $173.5 \mathrm{~m}$ in Merevale Borehole 1 , values of $\delta^{13} \mathrm{C}_{\text {org }}$ are relatively stable within the range -29.7 to $-29.1 \%$ (Fig. 5), and are taken to represent typical background values against which to assess the development of excursions. Below $85 \mathrm{~m}$ depth in Merevale Borehole $3, \delta^{13} \mathrm{C}_{\text {org }}$ is significantly lower, falling to a minimum of $-31.6 \%$ in the $7 \mathrm{~m}$ interval above a thick sill (with its top at $91.75 \mathrm{~m}$; Fig. 5). This sharp decline is attributed to the impact of the sill on the carbon isotope values of the immediately adjacent mudstones. The fact that this lowering of $\delta^{13} \mathrm{C}_{\text {org }}$ is stratigraphically confined to a narrow (ca $7 \mathrm{~m}$ ) interval above the sill strongly suggests that the igneous intrusions in the Outwoods Shale Formation have not significantly compromised the primary carbon isotope composition of the formation as a whole. A similar local effect is seen in mudstones adjacent to a sill intruding the sampled outcrop succession in Oldbury Quarry (Fig. 6). In general, the effect of diagenesis on $\delta^{13} \mathrm{C}$ values is relatively limited (Sharp, 2007), as demonstrated by the survival of the SPICE signature in highly altered, dolomitised and ore-bearing rocks (He, 1995; Saltzman et al., 2000). The consistent trend and biostratigraphical correlation of the SPICE in the Nuneaton succession (Fig. 5, 7) with SPICE signatures from elsewhere strongly indicate the general robustness of our $\delta^{13} \mathrm{C}$ values.

TOC values for the sampled succession are low, averaging around $2 \%$, with high frequency oscillations through much of the succession probably reflecting primary alternations in the sedimentary environment (see above). Within a few metres of igneous intrusions TOC values are generally lower and less variable, consistent with these bodies having a localised geochemical impact.

\section{Global Comparison}

The development of a significant positive CIE, spanning the bulk of the Olenus Biozone (Excursion 1) in the Outwoods Shale Formation, clearly correlates with the late Cambrian SPICE. Published biostratigraphical data provide strong evidence for independent correlation of the Olenus Biozone of the English late Cambrian with the basal Furongian and coeval North American Steptoean succession, including the presence of the global index trilobite species Glyptagnostus reticulatus (Taylor \& Rushton, 1971; Rushton, 1983; Fig. 7). Whilst acknowledging that $\delta^{13} \mathrm{C}$ values dervied from organic and carbonate sources can vary (Young et al, 2008), it is interesting to note that the amplitude of the excursion in the Outwoods Shale Formation $(4.1 \%$ ) is only slightly lower than the maximum (5\%) documented for the SPICE in the carbonate-dominated successions $\left(\delta^{13} \mathrm{C}_{\text {carb }}\right)$ in North America, and is 
substantially greater than that determined for organic-rich mudstones $\left(\delta^{13} \mathrm{C}_{\mathrm{org}}\right)$ of southern Sweden (1.5 to 2.0\%o) (Saltzman et al., 2004; Ahlberg et al., 2009).

Figure 7 shows a comparison of the Outwoods Shale Formation $\delta^{13} \mathrm{C}_{\text {org }}$ curve with worldwide signatures (both $\delta^{13} \mathrm{C}_{\text {org }}$ and $\delta^{13} \mathrm{C}_{\text {carb }}$ ) documented for the SPICE, using the first appearance of the cosmopolitan agnostoid Glyptagnostus reticulatus as a common datum. Although similarity of $\delta^{13} \mathrm{C}_{\text {org }}$ and $\delta^{13} C_{\text {carb }}$ signatures is not necessarily to be expected even from the same succession (Young et al., 2008), there is a striking general correspondence of these global curves. The Avalonian $\left(\delta^{13} \mathrm{C}_{\text {org }}\right)$ and Siberian $\left(\delta^{13} \mathrm{C}_{\text {carb }}\right)$ signatures match in the general form of the SPICE peak and in the development of a higher secondary peak, although independent evidence for correlation of the Siberian 'post SPICE' peak and Excursion 2 is lacking. Differences between $\delta^{13} \mathrm{C}_{\text {org }}$ and $\delta^{13} \mathrm{C}_{\text {carb }}$ are usually caused by fractionation effects (especially photosynthetic fractionation) that are largely controlled by water temperature, concentration of dissolved carbon dioxide and nutrient supply (Young et al., 2008). Decreased isotopic difference between $\delta^{13} C_{\text {org }}$ and $\delta^{13} C_{\text {carb }}$ signatures in the Ordovician has previously been attributed to critically high or low concentrations of atmospheric carbon dioxide (Young et al., 2008, and references therein); perhaps the general similarity of the Avalonian and Siberian curves on Figure 7, which occupy distinctly different palaeolatitudes (Fig. 1), might be similarly interpreted. Although high carbon dioxide is favoured by established views of the late Cambrian palaeoenvironment, evidence for at least periodically low atmospheric carbon dioxide has recently been inferred from latest Furongian equatorial beach deposits, allegedly showing evidence of freeze-thaw effects (Runkel et al., 2010).

It is notable that the SPICE in England, and to a lesser extent in Siberia, is characterised by a long and gradual upward decline in $\delta^{13} \mathrm{C}_{\text {org }}$ above the peak $\mathrm{CIE}$. In some other successions the decline in values above the peak of the SPICE is more abrupt, which may be influenced by sampling density and/or stratigraphical completeness. In the case of the Nevada succession, this may be caused by erosion associated with a proposed drop in sea level near the peak of the SPICE (Saltzman et al., 2004; Peng et al., 2004).

\section{Lithofacies and sea level}

To investigate if there is any significant relationship between the development of the positive $\delta^{13} \mathrm{C}_{\text {org }}$ excursion and lithofacies in the English succession, graphic outline lithological logs have been generated from the published descriptions of the Merevale boreholes (Taylor \& Rushton, 1971; Fig. 5). These logs do not show an exact relationship between the onset of the SPICE and lithofacies changes. However, the relatively sudden appearance of phosphatic nodules a few metres above the base of the SPICE, closely associated with a concentration of thin 'glauconitic' sandstone lenses, may indicate a sharp reduction in rates of deposition. This is most consistent with a marine transgression and subsequent highstand, where rapid deepening starves the shelf of sediment (Huggett \& Gale, 1997). Burrowing and the frequency of thin sandstones both gradually decline as $\delta^{13} \mathrm{C}_{\text {org }}$ values 
continue to rise in the upper part of the Merevale 3 Borehole (Fig. 5). These features could also indicate marine deepening, leading to reduced circulation and the more frequent establishment of seabed anoxia. If the sandstones represent intermittent high-density gravity flows, as suggested by Bridge et al. (1998), then the creation of extra accommodation space at the basin margins would reduce their development and extent in shelf successions, and further promote the establishment of oxygen-poor environments.

There are no major lithofacies changes associated with the development of the peak of the SPICE in the Outwoods Shale Formation, nor any evidence of a eustatic fall in sea level (Fig. 6). The estimated magnitude of the eustatic change in North America is modest (ca 25 m; Saltzman et al., 2000), and may have been compensated for by more active basin subsidence affecting the English succession, or masked by the relatively greater depth of the basin. The record of phosphatic nodules in the relatively narrow interval spanning the upper part of the Oldbury Quarry and basal $13 \mathrm{~m}$ of Outwoods Shale Formation in Merevale Borehole 1 (Fig. 5, 6), might suggest a brief period of reduced sedimentation rates and/or current winnowing.

Published data for southern Britain show a pulsed rise in sea level throughout the Cambrian, culminating in a late Cambrian highstand during which there were three cycles of fall and rise in sea level associated with faunal changes (Woodcock, 2000). Little has been published on the detailed sequence stratigraphy of the Cambrian in southern Britain. However, data for the Welsh Basin suggests that relatively few of the Cambrian sequences recognised in this area are likely to be purely eustatic in origin (Woodcock, 1990).

\section{Faunal Diversity \& Extinction}

Major trilobite faunal changes accompany the development of the SPICE in North America, Kazakhstan and China (Saltzman et al., 2000), but in the Outwoods Shale Formation the relationship appears more subtle. Furongian trilobite faunas of Avalonia and Baltica belong to the Olenid Biofacies that developed in response to oxygen-deficient marine environments characterised by mudstone deposition. In contrast, coeval faunas in Laurentia inhabited carbonate-dominated marine shelves, and show much higher overall diversity. Despite these difficulties of comparison, the sporadic faunal evidence from the Outwoods Shale Formation is that there is no direct analogue of the trilobite extinction event that heralds the onset of the SPICE elsewhere. This might simply be explained by the fact that the Avalonian trilobites already occupied challenging palaeoenvironments, and that the SPICE, and its environmental consequences, simply had a lower impact on these faunas. In Baltica, where the trilobite fauna is broadly comparable to Avalonia, the replacement of trilobites by phosphatocopids in the top of the $A$. pisiformis Biozone suggests that palaeoenvironmental conditions were already inhospitable immediately prior to the development of the SPICE and the appearance of Olenus (Williams et al., 1994).

Although faunal data from the Outwoods Shale Formation are based on collecting from limited diameter borehole core and sampling of discontinuous 
outcrops, there is some evidence for slightly more diverse trilobite faunas in the higher part of the Olenus Biozone (Rushton, 1983). Some 15 trilobite taxa occur in the $O$. cataractes Subzone (spanning the peak and falling limb of the $\mathrm{CIE}$ ) compared to 9 taxa in the lower part of the Olenus Biozone. This pattern is somewhat analogous to trilobite diversity trends reported for North America (Saltzman et al., 2000). The O. cataractes Subzone fauna includes non-olenid forms, such as agnostoids, Proceratopyge, Irvingella and Cliffia? (Rushton, 1983). Based on the horizon of the trilobite inceptions recorded by Rushton (1983), the bulk of the taxa in the O. cataractes Subzone appear just above the peak of the SPICE (i.e. above the peak of Excursion 1 on Fig. 5). Of the 4 taxa that appear around the peak of the CIE, 3 have, so far as is known, very limited ranges, and may reflect niche exploitation by a trilobite fauna that was adapted to adverse palaeoenvironments. The remainder of the $O$. cataractes Subzone fauna could, at least in part, reflect faunal recovery following the extreme environmental perturbation recorded by the SPICE. In more condensed successions and/or where a drop in sea level and possible erosion are coincident with the peak of the SPICE, faunas in the overlying succession might appear to be artificially close to the CIE peak, making an assessment of the impact of the CIE on diversification trends less straightforward.

New palaeontological data for the Oldbury Quarry succession show that the biota is dominated by algal remains, described by Taylor and Rushton (1971) as resembling such Cambrian algae as Morainia, Bosworthia and Yuknessia. There are also infrequent specimens of the possibly worm-like "Problematicum A" described by Taylor and Rushton (1971, p. 25).

Calcareous fossils are very rare, comprising a single indeterminate agnostoid. Phosphatic fossils include two small lingulate brachiopods and three phosphatocopids; a possible specimen of Veldotron suggests correlation with the O. cataractes Subzone, based on records by Williams and Siveter (1998). The sparseness of fauna is consistent with the general faunal character of the higher part of the Outwoods Shale Formation (despite the slightly greater diversity over this interval), and with the coeval higher part of the Alum Shale Formation in Sweden. Schovsbo (2007) attributed the lack of fauna in the Swedish succession to reduced preservation of calcareous faunas; there, times of increased bottom-water aeration caused generation of corrosive pore waters through oxidation of sulphides, reducing the preservation potential of calcareous remains. The same process may be applicable to the Nuneaton succession, reflecting oxygen recovery of the marine environment following the peak of the SPICE near the base of the Oldbury Quarry succession.

\section{Driving mechanisms for SPICE}

Previous attempts to understand the mechanism(s) controlling the development of SPICE have focussed on the relationship of the positive CIE to inferred sea level change and to patterns of biotic change in trilobite populations (Saltzman et al., 2004; Zhu et al., 2006). Lithological evidence, tentatively suggesting that the onset of the SPICE in the Outwoods Shale Formation coincides with a reduction in sedimentation triggered by a relative 
rise in sea level, is consistent with a widely inferred eustatic rise at the base of the Furongian (Peng et al., 2004). The association of a eustatic rise in sea level with positive CIEs is also a feature developed in Mesozoic successions (Jones \& Jenkyns, 2001). Some previous research has suggested that the SPICE was caused by a slightly later Furongian regression event that appears to be coincident with the CIE peak in Laurentia (Saltzman et al., 2004). Evidence from the $\delta^{13} \mathrm{C}_{\text {org }}$ data from the Outwoods Shale Formation suggests that a positive trend in $\delta^{13} \mathrm{C}$ values was already well established below the peak of SPICE. Apparent diachroneity of the onset and peak of the SPICE, discussed by Ahlberg et al. (2009), is attributed to uncertainties in biostratigraphical resolution and variable sampling techniques. Consequently, this later marine regression does not appear to be strongly implicated in triggering the SPICE, and possible scenarios linked to regression (Glumac \& Walker, 1998; Saltzman et al., 2004) involving increased sediment deposition and enhanced burial of carbon, or changes in the weathering patterns induced by exposure of shelf margins, seem less plausible explanations. In fact, evidence suggests that there is likely to be a stronger correlation between regression and lowering of $\delta^{13} \mathrm{C}$ (Ripperdan, 2002).

The global record for the Cambrian shows that CIEs occurred with remarkable frequency in the earliest Palaeozoic (Zhu et al., 2006, fig. 1) compared to the Mesozoic and Cenozoic, suggesting that features of the Cambrian made the carbon cycle inherently more sensitive to perturbation. The evidence from the Alum Shale Formation in southern Sweden (Thickpenny, 1987) indicates that parts of the marine ecosystem remained poorly oxygenated for long periods of the early Palaeozoic, beyond those times characterised by positive $\delta^{13} \mathrm{C}$ excursions. This may suggest that large parts of the late Cambrian marine realm were relatively closer to tipping points, and therefore more strongly influenced by smaller degrees of change to critical parameters. More generally, Gill et al. (2007b) suggested that the Palaeozoic was a transitional interval between rapid isotopic variability in Proterozoic oceans, to more gradual change in the Mesozoic and Cenozoic. In this context, it might not be necessary to invoke geologically infrequent large-scale changes in ocean circulation pattern (Saltzman et al., 2000) to explain significant shifts in the ${ }^{13} \mathrm{C}$ pool.

The combination of environmental circumstances that led to the SPICE remains enigmatic. Enhanced organic productivity and its burial in an expanded marine oxygen minimum zone seem the most likely processes, as evidenced by some data showing a positive sulphur isotope excursion that parallels SPICE (Gill et al., 2007a, b). In this context, the strongly symmetrical topology of SPICE seen in the high-resolution data for the Nuneaton succession (Figs 5,7 ), and in particular its gradual build-up and decline, is speculative evidence for the CIE being a biotic response to biolimiting resources. A basal Furongian eustatic sea level rise could have delivered a powerful nutrient pulse to the oceans, as suggested by Cowan et al. (2003). Given the evidence for generally poor ocean ventilation in the mid and late Cambrian, the resulting increase in surface water productivity would have favoured enhanced burial of organic matter, and a trend to more positive $\delta^{13} \mathrm{C}$ values. In this scenario, peak SPICE would reflect maximum biotic response 
to the nutrient bonanza, and declining SPICE and return to background $\delta^{13} \mathrm{C}$ values a response to progressive exhaustion of this resource. Subsequent widespread sea level fall and erosion, apparently coincident with peak SPICE in North America (Saltzman et al., 2000), but possibly post-dating this horizon (see Faunal Diversity \& Extinction), could have recycled basin-margin sediments enriched in $\delta^{13} \mathrm{C}$, and led to the formation of the 'Post-SPICE Peak' (Fig. 7). The absence of widespread late Cambrian black shale deposits remains a problem for this and other productivity-centred hypotheses. In some parts of the world, these deposits might survive as Cambrian graphite-rich units in metamorphic complexes (B. Windley, oral communication, 2010).

In the late Cambrian, continental masses were concentrated in the southern hemisphere and Gondwana was undergoing extreme levels of chemical weathering producing vast deposits of quartz-rich sandstone and thick offshore marine fan deposits (Álvaro et al.,2008, fig. 2; Avigad et al., 2005; Fig. 1 ). This may have profoundly affected marine geochemistry, and data from strontium isotopes appear to confirm the unique importance of chemical weathering on ocean geochemistry in the late Cambrian compared to submarine hydrothermal circulation (Kouchinsky et al., 2008). Goddéris et al. (2001) have suggested that the early Palaeozoic carbon cycle was significantly influenced by the progressive oxidation of a large reduced carbon reservoir exhumed during the Pan-African Orogeny.

Fuller explanation of the SPICE may depend on a more complete understanding of the role of these factors, rather than relying solely on traditional assumptions about the biotic response to changes in sea level and ocean circulation.

\section{Conclusions}

The late Cambrian (Furongian) Outwoods Shale Formation seen in boreholes and outcrop in Warwickshire, England, preserve a relatively expanded positive $\delta^{13} \mathrm{C}_{\text {org }}$ excursion occupying the greater part of the Olenus Biozone (= G. reticulatus Biozone of Terfelt et al., 2008). This excursion is identified as the SPICE, a globally developed positive $\delta^{13} \mathrm{C}$ excursion not previously recognised in Avalonia. The excursion spans an interval of $145 \mathrm{~m}$, with maximum amplitude of $4.1 \%$, and is largely unaffected by the presence of Ordovician igneous intrusions. The SPICE signature in the Outwoods Shale Formation appears to have a particularly protracted upper limb, perhaps partly unrepresented in North American successions because of erosion associated with a lowstand. The Outwoods Shale Formation also shows the development of a smaller positive $\delta^{13} \mathrm{C}_{\text {org }}$ excursion, spanning an interval of ca $25 \mathrm{~m}$ in the topmost Olenus Biozone and basal $P$. spinulosa Biozone, with a maximum amplitude of $1.1 \%$. This smaller CIE is superficially very similar to the 'PostSPICE' feature recognised in Siberia.

The relatively shallow, mid-shelf environment with intermittently anoxic and sub-oxic conditions, in which the siliciclastic sediment of the Outwoods Shale Formation was deposited, contrasts with the shallow, well-aerated, basin- 
margin, carbonate-dominated succession of North America, and with the shallow, sediment-starved, poorly oxygenated epicontinental sea in which the organic-rich mudstones of the Alum Shale Formation accumulated.

Recognition of the SPICE in the English late Cambrian succession is valuable for global correlation, and may also point to the greater importance of the basal Furongian marine transgression, and possible associated nutrient and productivity pulses, in creating the CIE. The base of the SPICE in the Outwoods Shale Formation is represented by a very distinct positive shift in $\delta^{13} \mathrm{C}_{\text {org }}$ values, significantly below the CIE peak. This suggests that a slightly later regressive event, that has been linked with the positive CIE peak in North America and elsewhere, might not be directly related to the cause of the excursion as has been postulated by some previous research.

The relatively high frequency of carbon isotope excursions in the Cambrian suggests that processes that drove changes in the Mesozoic $\delta^{13} \mathrm{C}$ profile might not fully explain events like the SPICE. Geological processes specific to the Cambrian, such as extreme chemical weathering of Gondwana, palaeogeographic configuration, or ecosystem simplicity could have had a significant role in making this interval of geological time more prone to perturbations of the carbon cycle.

\section{Acknowledgements}

We are grateful to C. Thomas and S. G. Molyneux (BGS), and Prof. Brian Windley (University of Leicester) and Dr. Howard Armstong (University of Durham) for valuable discussion and comment on earlier drafts of this manuscript. G. K. Lott (BGS) provided valuable assistance in the field.

\section{References}

Ahlberg, P., Axheimer, N., Babcock, L. E., Eriksson, M. E., Schmitz, B. \& Terfelt, F. 2009. Cambrian high-resolution biostratigraphy and carbon isotope chemostratigraphy in Scania, Sweden: first record of the SPICE and DICE excursions in Scandinavia. Lethaia, 42, 2 - 16.

Allen, P. M. \& Jackson, A. A. 1985. Geology of the country around Harlech. Memoir of the British Geological Survey. 1:50 000 Sheet 135 (England \& Wales).

Álvaro, J. J. Subías, B. B. I., Pierre, C. \& Vizcaïno, D. 2008. Carbon chemostratigraphy of the Cambrian - Ordovician transistion in a midlatitude mixed platform, Montagne Noir, France. Bulletin of the Geological Society of America, 120, 962 - 975.

Avigad, D., Sandler, A., Kolodner, K., Stern, R. J., McWilliams, M., Miller, N. \& Beyth, M. 2005. Mass-production of Cambro-Ordovician quartz-rich sandstone as a consequence of chemical weathering of Pan-African terranes: 
environmental implications. Earth and Planetary Science Letters, 240, 818 826.

Brasier, M. D. 1993. Towards a carbon isotope stratigraphy of the Cambrian System: potential of the Great Basin succession. Geological Society of London, Special Publication, 70, 341 - 350.

Brenchley, P. J., Rushton, A. W. A., Howells, M. \& Cave, R. 2006. Cambrian and Ordovician: the early Palaeozoic tectonostratigraphic evolution of the Welsh Basin, Midland and Moinian Terranes of Eastern Avalonia. 25 - 74 in The Geology of England and Wales. Brenchley, P. J. \& Rawson, P. F. (eds) (London: The Geological Society.)

Bridge, D.M., Carney, J.N., Lawley, R.S., Rushton, A.W.A., Baldock, J.W., Old, R.A., Rees, J.G., Sumbler, M.G., Pharaoh, T.C., Brewer, T.S., Henney, P.J., Webb, P.C., Merriman, R.J., Jones, N.S., Riley, N.J., Hallsworth, C.R., Haslam, H.W., Cornwell, J.D., Royles, C.P., Cheney, C.S. \& Fenwick, S.M.M. 1998. Geology of the country around Coventry and Nuneaton. Memoir of the British Geological Survey. 1:50 000 Sheet 169 (England \& Wales).

Cocks, L. R. M. \& Torsvik, T. H. 2002. Earth history from 500 to 400 million years ago: a faunal and palaeomagnetic review. Journal of the Geological Society, London, 159, $631-644$.

Cook, H. E, Taylor, M. E., Zhemchuzhnikov, S. V., Apollonov, M. K., Ergaliev, G. K., Sargaskaev, Z. S. \& Dubinina, S. V. 1991. Comparison of two early Paleozoic carbonate submarine fans - western US and southern Kazakhstan. 847 - 872 in Paleozoic Palaeogeography of the Western United States - II. Field Trip Guidebook Pacific Section Society of Economic Paleontologists and Mineralogists, 67.

Cope, J. C. W. , Ingham, J. K., \& Rawson, P. F. (eds). 1992 Atlas of Palaeogeography and Lithofacies. Geological Society, London, Memoir 13.

Cowan, C. A., Runkel, A. C. \& Saltzman, M. R. 2003. The effect on paleoproductivity of the first major delivery of mid Laurentian saprolite-derived material to Phanerozoic oceans: continent-wide marine ravinement during submergence-emergence of Late Cambrian North America, and the global carbon isotope SPICE event. Geological Society of America, Abstracts with Programs, 35 (6), 458.

Cowie, J. W., Rushton, A. W. A., \& Stubblefield, C. J. 1972. A Correlation of Cambrian Rocks in the British Isles. Special Report of the Geological Society, London, 2.

Cramer, B. D. \& Saltzman, M. R. 2007. Fluctuations in epeiric sea carbonate production during Silurian positive carbon isotope excursions: A review of proposed paleoceanographic models. Palaeogeography, Palaeoclimatology, Palaeoecology, 245, $37-45$. 
Gill, B., Kump, L., Young, S. \& Saltzman, M. R. 2007a. A Late Cambrian oceanic anoxic event. Geological Society of America, Abstracts with Programs, 39(6), 304.

Gill, B. C., Lyons, T. W., \& Saltzman, M. R. 2007b. Parallel, high-resolution carbon and sulfur isotope records of the evolving Palaeozoic marine sulphur reservoir. Palaeogeography, Palaeoclimatology, Palaeoecology, 256, 156 173.

Glumac, B. \& Walker, K. R. 1998. A Late Cambrian positive carbon-isotope excursion in the southern Appalacians: relation to biostratigraphy, sequence stratigraphy, environments of deposition and diagenesis. Journal of Sedimentary Research, 68, 1212 - 1222.

Goddéris, Y., François, L. M. \& Veizer, J. 2001. The early Paleozoic carbon cycle. Earth and Planetary Science Letters, 190, 181 - 196.

He, Z. 1995. Sedimentary facies and variation of stable isotope composition of Upper Cambrian to Lower Ordovician strata in southern Missouri: implications for the origin of MVT deposits and the geochemical and hydrological features of regional ore-forming fluids. PhD thesis. Rolla, University of Missouri, 124 pp.

Howell, B. F., Bridge, J., Deiss, C. F., Edwards, I., Lochman, C., Raasch, G. O., \& Resser, C. E. 1944. Correlation of the Cambrian formations of North America. Bulletin of the Geological Society of America, 55, 993 - 1003.

Howells, M. F. 2007. British Regional Geology: Wales (Keyworth, Nottingham: British Geological Survey.)

Howells, M. F. \& Smith, M. 1997. Geology of the country around Snowdon. Memoir of the British Geological Survey. 1:50 000 Sheet 119 (England \& Wales).

Huggett, J. M. \& Gale, A. S. 1997. Petrology and palaeoenvironmental significance of glaucony in the Eocene succession at Whitecliff Bay, Hampshire Basin, UK. Journal of the Geological Society, London, 154, 897 912.

Hurtgen, M. T., Pruss, S. B. \& Knoll, A. H. 2009. Evaluating the relationship between the carbon and sulphur cycles in the later Cambrian ocean: An example from the Port au Port Group, western Newfoundland, Canada. Earth and Planetary Science Letters, 281, 288 - 297.

Jones, C. E. \& Jenkyns, H. C. 2001. Seawater strontium isotopes, oceanic anoxic events, and seafloor hydrothermal activity in the Jurassic and Cretaceous. American Journal of Science, 301, $112-149$. 
Kouchinsky, A., Bengtson, S., Gallet, Y., Korovnikov, I., Pavlov, V., Runnegar, B., Shields, G., Veizer, J., Young, E. \& Ziegler, K. 2008. The SPICE carbon isotope excursion in Siberia: a combined study of the upper Middle Cambrian - lowermost Ordovician Kulyumbe River section, northwestern Siberian Platform. Geological Magazine,145, 609 - 622.

Landing, E. \& MacGabhann, B. A. 2010. First evidence for Cambrian glaciation provided by sections in Avalonian New Brunswick and Ireland: Additional data for Avalon - Gondwana separation by the earliest Palaeozoic. Palaeogeography, Palaeoclimatology, Palaeoecology, 285, 174- 185.

Ludvigsen, R. \& Westrop, S. R. 1985. Three new Upper Cambrian stages for North America. Geology, 13, 139 - 143.

Peng, S. \& Babcock, L. 2008. 4 Cambrian Period. 37 - 46 in The Concise Geologic Time Scale. Ogg, J. G., Ogg, G. \& Gradstein, F. M. (eds.). (Cambridge: Cambridge University Press.)

Peng, S., Babcock, L. E., Robison, R. A, Lin, H., Rees, M. N. \& Saltzman, M. R. 2004. Global Standard Stratotype-section and Point of the Furongian Series and Paibian Stage (Cambrian). Lethaia, 37, 365 - 379.

Pratt, W. I., Woodhall, D. G. \& Howells, M. F. 1995. Geology of the country around Cadair Idris. Memoir of the British Geological Survey. 1:50 000 Sheet 149 (England \& Wales).

Raymo, M. E. 1991. Geochemical evidence supporting T. C. Chamberlin's theory of glaciation. Geology, 19, $344-347$.

Ripperdan, R. L. 2002. The HERB event: end of the Cambrian carbon cycle paradigm? Geological Society of America, Abstracts with Programs, 34, 413.

Runkel, A. C., Mackey, T. J., Cowan, C. A. \& Fox, D. L. 2010. Tropical shoreline ice in the late Cambrian: Implications for Earth's climate between the Cambrian Explosion and the Great Ordovician Biodiversification Event. GSA Today, 20, $4-10$.

Rushton, A. W. A. 1978. Fossils from the Middle - Upper Cambrian transition in the Nuneaton district. Palaeontology, 21, $245-283$.

Rushton, A. W. A. 1983. Trilobites from the Upper Cambrian Olenus Zone in Central England. Special Papers in Palaeontology, 30, 107-139.

Rushton, A. W. A. 1999. Chapter 5. Cambrian rocks of England. $71-87$ in British Cambrian to Ordovician stratigraphy, Rushton, A. W. A., Owen, A. W., Owens, R. M., \& Prigmore, J. K. Geological Conservation Review Series, 18. (Peterborough: Joint Nature Conservation Committee.)

Rushton, A. W. A. \& Weidner, T. 2010. The Furongian trilobite Irvingella from Jämtland and Ångermanland, Sweden. GFF, 132, 193 - 200. 
Rushton, A. W. A., Owen, A. W., Owens, R. M. \& Prigmore, J. K. 1999. British Cambrian to Ordovician Stratigraphy. Geological Conservation Review Series, 18.

Saltzman, M. R., Brasier, M. D, Ripperdan, R. L., Lohmann, K. C. \& Runnegar, B. 1995. A large and global positive carbon-isotope excursion during the Late Cambrian: Correlation with marine extinctions and sea-level fluctuations. Geological Society of America, Abstracts with Programs, 27(6), 331.

Saltzman, M. R., Runnegar, B, \& Lohmann, K. C. 1998. Carbon isotope stratigraphy of Upper Cambrian (Steptoean Stage) sequences of the eastern Great Basin: Record of a global oceanographic event. Bulletin of the Geological Society of America, 110, 285 - 297.

Saltzman, M. R., Ripperdan, R. L., Brasier, M. D., Lohmann, K. C., Robison, R. A., Chang, W. T., Peng, S., Ergaliev, E. K. \& Runnegar, B. 2000. A global carbon isotope excursion (SPICE) during the Late Cambrian: relation to trilobite extinctions, organic-matter burial and sea level. Palaeogeography, Palaeoclimatology, Palaeoecology,162, 211 - 223.

Saltzman, M. R., Cowan, C. A., Runkel, A. C., Runnegar, B., Stewart, M. C. \& Palmer, A. R. 2004. The Late Cambrian SPICE $\left(\delta^{13} C\right)$ event and the Sauk II Sauk III regression: new evidence from laurentian basins in Utah, lowa and Newfoundland. Journal of Sedimentary Research, 74, 366 - 377.

Schovsbo, N. H. 2007. Why barren intervals? A taphonomic case study of the Scandinavian Alum Shale and its faunas. Lethaia, 34, 271 - 285.

Sharp, Z. 2007. Principles of Stable Isotope Geochemistry. (Upper Saddle River, New Jersey: Pearson Prentice Hall.)

Taylor, K. \& Rushton, A. W. A. 1971. The pre-Westphalian geology of the Warwickshire Coalfield. Bulletin of the Geological Survey of Great Britain, 35, 150 pp. [Published 1972]

Terfelt, F., Eriksson, M. E., Ahlberg, P. \& Babcock, L. E. 2008. Furongian Series (Cambrian) biostratigraphy of Scandinavia - a revision. Norwegian Journal of Geology, 88, 73 - 87.

Thickpenny, A. 1984. The sedimentology of the Swedish Alum Shales. 511 525 in Pelagites and Organic-Rich Sediments. Special Publication of the Geological Society, London,15.

Thickpenny, A. 1987. Palaeo-oceanography and depositional environment of the Scandinavian Alum Shales: sedimentological and geochemical evidence. 156 - 171 in Marine Clastic Sedimentology. Leggett, J. K. \& Zuffa, G. G. (eds) (London: Graham \& Trotman.) 
Young, S. A., Saltzman, M. R., Bergström, S. M., Leslie, S. A. \& Xu, C. 2008. Paired $\delta^{13} \mathrm{C}_{\text {carb }}$ and $\delta^{13} \mathrm{C}_{\text {org }}$ records of Upper Ordovician (Sandbian - Katian) carbonates in North America and China: Implications for paleoceanographic change. Palaeogeography, Palaeoclimatology, Palaeoecology, 270, 166 178.

Williams, M., Siveter, D.J., Rushton, A.W.A. \& Berg-Madsen, V. 1994. The upper Cambrian bradoriid ostracod Cyclotron lapworthi is a hesslandonid. Transactions of the Royal Society of Edinburgh, Earth Sciences, 85, 123 130.

Williams, M. \& Siveter, D. J. 1998. British Cambrian and Tremadoc bradoriid and phosphatocopid arthropods. Monograph of the Palaeontographical Society, London. Publication Number 607, part of Volume 152 for 1998.1 $49 \& 6$ pls.

Woodcock, N. 1990. Sequence stratigraphy of the Palaeozoic Welsh Basin. Journal of the Geological Society, London, 147, 537 - 547.

Woodcock, N. 2000. The Cambrian and earliest Ordovician quiescent margin of Gondwana. 141 - 152 in Geological History of Britain and Ireland.

Woodcock, N. \& Strachan, R. (eds). (London: Blackwells.)

Young, T. P., Gibbons, W. \& McCarroll, D. 2002. Geology of the country around Pwllheli. Memoir of the British Geological Survey. 1:50 000 Sheet 134 (England \& Wales).

Zhu, M.-Y., Babcock, L. E \& Peng, S.-C. 2006. Advances in Cambrian stratigraphy and paleontology: integrating correlation techniques, paleobiology, taphonomy and paleoenvironmental reconstruction. Palaeoworld, 15, $217-222$. 
Appendix 1 - Stable isotope analysis and total organic carbon (\%C) of bulk rock samples from the Outwoods Shale Formation in Merevale boreholes 1 and 3 and the Oldbury Quarry outcrop succession. Sample values likely to be affected by proximity to igneous intrusions are shown in bold.

\begin{tabular}{|c|c|c|c|c|c|}
\hline $\begin{array}{l}\text { BGS } \\
\text { Sample } \\
\text { No. }\end{array}$ & $\begin{array}{l}\text { Borehole I } \\
\text { Outcrop }\end{array}$ & $\begin{array}{l}\text { Borehole } \\
\text { depth } \\
\text { (ft / m) }\end{array}$ & Biozone & $\delta^{13} \mathrm{C}$ & $\% \mathrm{C}$ \\
\hline SSK3155 & Merevale Borehole 1 & 714 / 217.63 & O. cataractes & -27.7 & 0.4 \\
\hline SSK3156 & Merevale Borehole 1 & $710 / 216.40$ & O. cataractes & -28.3 & 2.9 \\
\hline SSK3157 & Merevale Borehole 1 & $706 / 215.19$ & O. cataractes & -27.7 & 0.5 \\
\hline SSK3158 & Merevale Borehole 1 & $702 / 213.97$ & O. cataractes & -27.7 & 0.3 \\
\hline SSK3159 & Merevale Borehole 1 & $698 / 212.75$ & O. cataractes & -28.3 & 1.5 \\
\hline SSK3160 & Merevale Borehole 1 & $694 / 211.53$ & O. cataractes & -28.3 & 0.9 \\
\hline SSK3161 & Merevale Borehole 1 & $690 / 210.31$ & O. cataractes & -28.2 & 0.6 \\
\hline SSK3163 & Merevale Borehole 1 & 682 / 207.87 & O. cataractes & -28.5 & 1.3 \\
\hline SSK3164 & Merevale Borehole 1 & $678 / 206.65$ & O. cataractes & -28.3 & 1.0 \\
\hline SSK3165 & Merevale Borehole 1 & $674 / 205.44$ & O. cataractes & -28.5 & 1.3 \\
\hline SSK3166 & Merevale Borehole 1 & $670 / 204.22$ & O. cataractes & -28.3 & 0.4 \\
\hline SSK3167 & Merevale Borehole 1 & $666 / 203.00$ & O. cataractes & -28.7 & 1.1 \\
\hline SSK3168 & Merevale Borehole 1 & 662 / 201.78 & O. cataractes & -28.5 & 0.3 \\
\hline SSK3169 & Merevale Borehole 1 & $658 / 200.56$ & O. cataractes & -28.7 & 1.7 \\
\hline SSK3170 & Merevale Borehole 1 & 654 / 199.34 & O. cataractes & -28.7 & 0.7 \\
\hline SSK3171 & Merevale Borehole 1 & $650 / 198.12$ & O. cataractes & -28.8 & 0.8 \\
\hline SSK3172 & Merevale Borehole 1 & $646 / 196.90$ & O. cataractes & -28.6 & 0.5 \\
\hline SSK3173 & Merevale Borehole 1 & 642 / 195.68 & O. cataractes & -28.8 & 0.9 \\
\hline SSK3175 & Merevale Borehole 1 & 634 / 193.24 & O. cataractes & -29.1 & 1.8 \\
\hline SSK3176 & Merevale Borehole 1 & $630 / 192.02$ & O. cataractes & -29.0 & 0.6 \\
\hline SSK3177 & Merevale Borehole 1 & $626 / 190.80$ & O. cataractes & -29.1 & 1.7 \\
\hline SSK3178 & Merevale Borehole 1 & $622 / 189.59$ & O. cataractes & -29.0 & 1.1 \\
\hline SSK3179 & Merevale Borehole 1 & $618 / 188.37$ & O. cataractes & -29.1 & 0.6 \\
\hline SSK3180 & Merevale Borehole 1 & $614 / 187.15$ & O. cataractes & -29.0 & 0.6 \\
\hline SSK3181 & Merevale Borehole 1 & $610 / 185.93$ & O. cataractes & -29.2 & 2.0 \\
\hline SSK3182 & Merevale Borehole 1 & $606 / 184.71$ & O. cataractes & -28.9 & 0.2 \\
\hline SSK3183 & Merevale Borehole 1 & $602 / 183.49$ & O. cataractes & -29.2 & 1.6 \\
\hline SSK3184 & Merevale Borehole 1 & $598 / 182.27$ & O. cataractes & -29.2 & 1.1 \\
\hline SSK3185 & Merevale Borehole 1 & $594 / 181.05$ & O. cataractes & -29.4 & 2.9 \\
\hline SSK3186 & Merevale Borehole 1 & $590 / 179.83$ & O. cataractes & -29.4 & 2.6 \\
\hline SSK3187 & Merevale Borehole 1 & $586 / 178.61$ & O. cataractes & -29.2 & 1.6 \\
\hline SSK3188 & Merevale Borehole 1 & $582 / 177.40$ & O. cataractes & -29.3 & 3.7 \\
\hline SSK3189 & Merevale Borehole 1 & $578 / 176.17$ & O. cataractes & -29.6 & 3.7 \\
\hline SSK3190 & Merevale Borehole 1 & $574 / 174.96$ & O. cataractes & -29.5 & 2.0 \\
\hline SSK3191 & Merevale Borehole 1 & $570 / 173.74$ & O. cataractes & -29.7 & 3.2 \\
\hline SSK3192 & Merevale Borehole 1 & $566 / 172.52$ & O. cataractes & -29.4 & 1.7 \\
\hline SSK3193 & Merevale Borehole 1 & $562 / 171.30$ & O. cataractes & -29.5 & 3.4 \\
\hline SSK3194 & Merevale Borehole 1 & 557 / 169.77 & O. cataractes & -29.6 & 2.3 \\
\hline SSK3195 & Merevale Borehole 1 & $554 / 168.86$ & O. cataractes & -29.4 & 0.7 \\
\hline SSK3196 & Merevale Borehole 1 & $550 / 167.64$ & O. cataractes & -29.7 & 2.2 \\
\hline SSK3197 & Merevale Borehole 1 & $546 / 166.42$ & O. cataractes & -29.8 & 2.7 \\
\hline SSK3198 & Merevale Borehole 1 & $542 / 165.20$ & O. cataractes & -29.6 & 1.9 \\
\hline SSK3199 & Merevale Borehole 1 & $539 / 164.29$ & O. cataractes & -29.5 & 2.0 \\
\hline SSK3200 & Merevale Borehole 1 & $533 / 162.46$ & O. cataractes & -29.7 & 2.4 \\
\hline
\end{tabular}




\begin{tabular}{|c|c|c|c|c|c|}
\hline SSK3201 & \begin{tabular}{|l|} 
Merevale Borehole 1 \\
\end{tabular} & $530 / 161.54$ & O. cataractes & -28.8 & 0.3 \\
\hline SSK3202 & Merevale Borehole 1 & $526 / 160.32$ & O. cataractes & -29.4 & 3.0 \\
\hline SSK3203 & \begin{tabular}{|l|} 
Merevale Borehole 1 \\
\end{tabular} & $522 / 159.10$ & O. cataractes & -29.1 & 1.8 \\
\hline SSK3204 & Merevale Borehole 1 & $518 / 157.89$ & O. cataractes & -29.1 & 2.5 \\
\hline SSK3205 & Merevale Borehole 1 & $514 / 156.67$ & O. cataractes & -29.4 & 2.3 \\
\hline SSK3206 & Merevale Borehole 1 & $510 / 155.45$ & O. cataractes & -28.8 & 0.2 \\
\hline SSK3207 & \begin{tabular}{|l|} 
Merevale Borehole 1 \\
\end{tabular} & $507 / 154.53$ & O. cataractes & -29.1 & 2.1 \\
\hline SSK3208 & Merevale Borehole 1 & $502 / 153.00$ & O. cataractes & -29.2 & 2.7 \\
\hline SSK3209 & \begin{tabular}{|l|} 
Merevale Borehole 1 \\
\end{tabular} & $498 / 151.79$ & O. cataractes & -28.8 & 1.2 \\
\hline SSK3210 & Merevale Borehole 1 & $494 / 150.57$ & O. cataractes & -29.3 & 2.1 \\
\hline SSK3211 & Merevale Borehole 1 & $490 / 149.35$ & O. cataractes & -29.1 & 2.3 \\
\hline SSK3212 & Merevale Borehole 1 & $486 / 148.13$ & O. cataractes & -28.8 & 0.6 \\
\hline SSK3213 & Merevale Borehole 1 & $482 / 146.91$ & O. cataractes & -29.2 & 2.9 \\
\hline SSK3214 & Merevale Borehole 1 & $478 / 145.69$ & O. cataractes & -29.2 & 2.0 \\
\hline SSK3215 & Merevale Borehole 1 & $475 / 144.78$ & O. cataractes & -29.0 & 3.1 \\
\hline SSK3216 & Merevale Borehole 1 & $470 / 143.26$ & P. spinulosa & -29.0 & 1.0 \\
\hline SSK3217 & Merevale Borehole 1 & $466 / 142.04$ & P. spinulosa & -29.4 & 1.0 \\
\hline SSK3218 & Merevale Borehole 1 & $462 / 140.82$ & P. spinulosa & -29.6 & 1.2 \\
\hline SSK3219 & Merevale Borehole 1 & $458 / 139.60$ & P. spinulosa & -29.5 & 1.1 \\
\hline SSK3220 & Merevale Borehole 1 & $454 / 138.38$ & P. spinulosa & -29.2 & 1.1 \\
\hline SSK3221 & Merevale Borehole 1 & $450 / 137.16$ & P. spinulosa & -29.6 & 0.9 \\
\hline SSK3222 & \begin{tabular}{|l|} 
Merevale Borehole 1 \\
\end{tabular} & $446 / 135.94$ & P. spinulosa & -29.9 & 1.6 \\
\hline SSK3223 & Merevale Borehole 1 & $442 / 134.72$ & P. spinulosa & -29.8 & 1.6 \\
\hline SSK3224 & Merevale Borehole 1 & $438 / 133.50$ & P. spinulosa & -29.5 & 0.9 \\
\hline SSK3225 & Merevale Borehole 1 & $434 / 132.28$ & P. spinulosa & -29.9 & 2.1 \\
\hline SSK3226 & Merevale Borehole 1 & $429 / 130.76$ & P. spinulosa & -29.6 & 1.7 \\
\hline SSK2793 & Merevale Borehole 3 & $292 / 89.00$ & A. pisiformis & -31.6 & 1.0 \\
\hline SSK2794 & Merevale Borehole 3 & $290 / 88.39$ & A. pisiformis & -30.7 & 0.3 \\
\hline SSK2795 & \begin{tabular}{|l|} 
Merevale Borehole 3 \\
\end{tabular} & $286 / 87.17$ & A. pisiformis & -30.3 & 0.3 \\
\hline SSK2796 & Merevale Borehole 3 & $278 / 84.73$ & A. pisiformis & -29.9 & 1.1 \\
\hline SSK2797 & Merevale Borehole 3 & $262 / 79.86$ & A. pisiformis & -29.5 & 0.5 \\
\hline SSK2798 & Merevale Borehole 3 & $240 / 73.15$ & A. pisiformis & -29.6 & 1.4 \\
\hline SSK2799 & Merevale Borehole 3 & $236 / 71.93$ & A. pisiformis & -29.4 & 1.1 \\
\hline SSK2800 & Merevale Borehole 3 & $232 / 70.71$ & A. pisiformis & -29.5 & 1.4 \\
\hline SSK2801 & \begin{tabular}{|l|} 
Merevale Borehole 3 \\
\end{tabular} & $228 / 69.49$ & A. pisiformis & -29.3 & 0.4 \\
\hline SSK2802 & Merevale Borehole 3 & $224 / 68.28$ & A. pisiformis & -29.3 & 1.6 \\
\hline SSK2803 & Merevale Borehole 3 & $220 / 67.06$ & A. pisiformis & -29.7 & 2.1 \\
\hline SSK2804 & Merevale Borehole 3 & $216 / 65.84$ & A. pisiformis & -29.5 & 1.6 \\
\hline SSK2805 & \begin{tabular}{|l} 
Merevale Borehole 3 \\
\end{tabular} & $212 / 64.62$ & A. pisiformis & -29.2 & 1.5 \\
\hline SSK2806 & Merevale Borehole 3 & $208 / 63.40$ & A. pisiformis & -29.5 & 0.7 \\
\hline SSK2807 & Merevale Borehole 3 & $204 / 62.18$ & A. pisiformis & -29.2 & 0.5 \\
\hline SSK2808 & \begin{tabular}{|l} 
Merevale Borehole 3 \\
\end{tabular} & $200 / 60.96$ & O. gibbosus & -29.4 & 1.0 \\
\hline SSK2809 & Merevale Borehole 3 & $198 / 60.35$ & O. gibbosus & -29.4 & 2.4 \\
\hline SSK2810 & Merevale Borehole 3 & $194 / 59.13$ & O. gibbosus & -29.3 & 0.7 \\
\hline SSK2811 & \begin{tabular}{|l} 
Merevale Borehole 3 \\
\end{tabular} & $190 / 57.91$ & O. gibbosus & -29.5 & 1.0 \\
\hline SSK2812 & Merevale Borehole 3 & $186 / 56.69$ & O. gibbosus & -29.2 & 0.5 \\
\hline SSK2813 & Merevale Borehole 3 & $182 / 55.47$ & O. gibbosus & -29.1 & 2.0 \\
\hline SSK2814 & \begin{tabular}{|l|} 
Merevale Borehole 3 \\
\end{tabular} & $178 / 54.25$ & O. gibbosus & -29.6 & 1.2 \\
\hline SSK2815 & Merevale Borehole 3 & $176 / 53.64$ & O. gibbosus & -29.2 & 0.8 \\
\hline SSK2816 & Merevale Borehole 3 & $170 / 51.82$ & O. gibbosus & -28.7 & 1.1 \\
\hline SSK2817 & \begin{tabular}{|l|} 
Merevale Borehole 3 \\
\end{tabular} & $166 / 50.60$ & O. gibbosus & -28.5 & 1.0 \\
\hline SSK2818 & Merevale Borehole 3 & $162 / 49.38$ & O. gibbosus & -28.7 & 1.2 \\
\hline SSK2819 & Merevale Borehole 3 & $158 / 48.16$ & O. gibbosus & -28.8 & 2.1 \\
\hline SSK2820 & Merevale Borehole 3 & $154 / 46.94$ & O. gibbosus & -28.6 & 1.4 \\
\hline SSK2821 & \begin{tabular}{|l|l} 
Merevale Borehole 3 \\
\end{tabular} & $150 / 45.72$ & O. gibbosus & -28.5 & 2.6 \\
\hline SSK2822 & Merevale Borehole 3 & $146 / 44.50$ & O. gibbosus & -28.1 & 1.9 \\
\hline
\end{tabular}




\begin{tabular}{|c|c|c|c|c|c|}
\hline SSK2823 & Merevale Borehole 3 & $142 / 43.28$ & O. gibbosus & -28.2 & 2.4 \\
\hline SSK2824 & Merevale Borehole 3 & $138 / 42.06$ & O. gibbosus & -28.4 & 3.8 \\
\hline SSK2825 & Merevale Borehole 3 & $134 / 40.84$ & O. gibbosus & -28.1 & 1.1 \\
\hline SSK2826 & Merevale Borehole 3 & $130 / 39.62$ & O. truncatus & -28.0 & 1.9 \\
\hline SSK2827 & Merevale Borehole 3 & $126 / 38.40$ & O. truncatus & -27.7 & 0.3 \\
\hline SSK2828 & Merevale Borehole 3 & $122 / 37.19$ & O. truncatus & -27.6 & 0.5 \\
\hline SSK2829 & Merevale Borehole 3 & $118 / 35.97$ & O. truncatus & -27.7 & 1.3 \\
\hline SSK3043 & Merevale Borehole 3 & $114 / 34.75$ & O. truncatus & -28.0 & 2.3 \\
\hline SSK3044 & Merevale Borehole 3 & $110 / 33.53$ & O. truncatus & -27.9 & 2.0 \\
\hline SSK3045 & Merevale Borehole 3 & $106 / 32.31$ & O. truncatus & -27.9 & 2.0 \\
\hline SSK3046 & Merevale Borehole 3 & $102 / 31.09$ & O. truncatus & -28.0 & 2.6 \\
\hline SSK3047 & Merevale Borehole 3 & $\begin{array}{l}978 "-99 / \\
29.77-30.18\end{array}$ & O. truncatus & -28.2 & 2.5 \\
\hline SSK3048 & Merevale Borehole 3 & $\begin{array}{l}89-91 / 27.13 \\
-27.74\end{array}$ & O. truncatus & -27.7 & 1.5 \\
\hline SSK3049 & Merevale Borehole 3 & $88 / 26.82$ & O. wahlenbergi & -28.2 & 1.9 \\
\hline SSK3050 & Merevale Borehole 3 & $84 / 25.60$ & O. wahlenbergi & -27.4 & 0.4 \\
\hline SSK3051 & Merevale Borehole 3 & $80 / 24.38$ & O. wahlenbergi & -27.4 & 1.0 \\
\hline SSK3052 & Merevale Borehole 3 & $78 / 23.77$ & O. wahlenbergi & -27.6 & 1.6 \\
\hline SSK3053 & Merevale Borehole 3 & $74 / 22.56$ & O. wahlenbergi & -27.8 & 2.3 \\
\hline SSK3054 & Merevale Borehole 3 & $72 / 21.95$ & O. wahlenbergi & -27.7 & 1.9 \\
\hline SSK3055 & Merevale Borehole 3 & $68 / 20.73$ & O. wahlenbergi & -27.2 & 0.4 \\
\hline SSK3056 & Merevale Borehole 3 & $\begin{array}{l}59-63 / 17.98 \\
-19.20\end{array}$ & O. wahlenbergi & -28.3 & 2.1 \\
\hline SSK3057 & Merevale Borehole 3 & $\begin{array}{l}556 "-586 " / \\
16.92-17.83\end{array}$ & bergi & -28.3 & 2.8 \\
\hline SSK3058 & Merevale Borehole 3 & $52 / 15.85$ & O. wahlenbergi & -28.3 & 1.5 \\
\hline SSK3059 & Merevale Borehole 3 & $48 / 14.63$ & O. wahlenbergi & -28.9 & 2.0 \\
\hline SSK3060 & Merevale Borehole 3 & $44 / 13.41$ & O. wahlenbergi & -27.4 & 0.2 \\
\hline SSK3061 & Merevale Borehole 3 & $40 / 12.19$ & O. wahlenbergi & -27.5 & 0.3 \\
\hline SSK3062 & Merevale Borehole 3 & $36 / 10.97$ & O. wahlenbergi & -27.8 & 1.4 \\
\hline SSK3063 & Merevale Borehole 3 & $32 / 9.75$ & O. wahlenbergi & -27.8 & 0.2 \\
\hline SSK3064 & Merevale Borehole 3 & $28 / 8.53$ & O. wahlenbergi & -27.5 & 1.2 \\
\hline SSK3065 & Merevale Borehole 3 & $24 / 7.32$ & O. wahlenbergi & -27.9 & 0.8 \\
\hline SSK3066 & Merevale Borehole 3 & $20 / 6.10$ & O. wahlenbergi & -27.9 & 0.7 \\
\hline SSK3067 & Merevale Borehole 3 & $16 / 4.88$ & O. wahlenbergi & -28.5 & 1.4 \\
\hline SSK3068 & Merevale Borehole 3 & $12 / 3.66$ & O. wahlenbergi & -28.8 & 0.7 \\
\hline SSK3069 & Merevale Borehole 3 & $8 / 2.44$ & O. wahlenbergi & -27.2 & 0.2 \\
\hline \multirow[t]{2}{*}{ SSK3070 } & Merevale Borehole 3 & $6 / 1.83$ & O. wahlenbergi & -27.2 & 0.2 \\
\hline & & $\begin{array}{l}\text { Height } \\
\text { above } \\
\text { outcrop } \\
\text { datum (m) }\end{array}$ & & & \\
\hline MR 42369 & Oldbury Quarry & 0 & O. cataractes & -26.6 & 0.2 \\
\hline MR 42370 & Oldbury Quarry & 1 & O. cataractes & -25.7 & 0.1 \\
\hline MR 42371 & Oldbury Quarry & 2 & O. cataractes & -25.6 & 0.1 \\
\hline MR 42372 & Oldbury Quarry & 3 & O. cataractes & -27.4 & 0.4 \\
\hline MR 42373 & Oldbury Quarry & 4 & O. cataractes & -26.5 & 0.4 \\
\hline MR 42374 & Oldbury Quarry & 5 & O. cataractes & -26.5 & 0.3 \\
\hline MR 42375 & Oldbury Quarry & 6 & O. cataractes & -27.2 & 0.6 \\
\hline MR 42376 & Oldbury Quarry & 7 & O. cataractes & -27.8 & 1.4 \\
\hline MR 42377 & Oldbury Quarry & 8 & O. cataractes & -27.8 & 1.4 \\
\hline MR 42378 & Oldbury Quarry & 9 & O. cataractes & -26.4 & 0.2 \\
\hline MR 42379 & Oldbury Quarry & 10 & O. cataractes & -27.6 & 1.7 \\
\hline MR 42380 & Oldbury Quarry & 11 & O. cataractes & -26.7 & 0.3 \\
\hline MR 42381 & Oldbury Quarry & 12 & O. cataractes & -26.8 & 1.9 \\
\hline MR 42382 & Oldbury Quarry & 13 & O. cataractes & -27.1 & 2.7 \\
\hline
\end{tabular}




\begin{tabular}{|l|l|l|l|l|l|}
\hline MR 42383 & Oldbury Quarry & 14 & O. cataractes & -27.3 & 2.9 \\
\hline MR 42384 & Oldbury Quarry & 15 & O. cataractes & -27.4 & 2.6 \\
\hline MR 42385 & Oldbury Quarry & 16 & O. cataractes & -27.5 & 2.8 \\
\hline MR 42386 & Oldbury Quarry & 17 & O. cataractes & -26.7 & 1.5 \\
\hline MR 42387 & Oldbury Quarry & 18 & O. cataractes & -26.8 & 1.8 \\
\hline MR 42388 & Oldbury Quarry & 19 & O. cataractes & -27.1 & 1.6 \\
\hline MR 42389 & Oldbury Quarry & 20 & O. cataractes & -27.4 & 2.6 \\
\hline MR 42390 & Oldbury Quarry & 21 & O. cataractes & -27.1 & 2.9 \\
\hline MR 42391 & Oldbury Quarry & 22 & O. cataractes & -27.4 & 3.4 \\
\hline MR 42392 & Oldbury Quarry & 23 & O. cataractes & -27.2 & 1.4 \\
\hline MR 42393 & Oldbury Quarry & 24 & O. cataractes & -27.2 & 2.9 \\
\hline MR 42394 & Oldbury Quarry & 25 & O. cataractes & -27.2 & 2.4 \\
\hline MR 42395 & Oldbury Quarry & 26 & O. cataractes & -27.7 & 3.2 \\
\hline MR 42396 & Oldbury Quarry & 27 & O. cataractes & -27.2 & 1.4 \\
\hline MR 42397 & Oldbury Quarry & 28 & O. cataractes & -27.7 & 3.1 \\
\hline MR 42398 & Oldbury Quarry & 29 & O. cataractes & -27.5 & 2.0 \\
\hline MR 42399 & Oldbury Quarry & 30 & O. cataractes & -29.5 & 1.6 \\
\hline MR 42400 & Oldbury Quarry & 38 & O. cataractes & -27.3 & 0.5 \\
\hline MR 42401 & Oldbury Quarry & 39 & O. cataractes & -27.3 & 0.8 \\
\hline MR 42402 & Oldbury Quarry & 40 & O. cataractes & -27.4 & 0.2 \\
\hline MR 42403 & Oldbury Quarry & 41 & O. cataractes & -27.6 & 0.5 \\
\hline MR 42404 & Oldbury Quarry & 42 & O. cataractes & -27.8 & 1.7 \\
\hline MR 42405 & Oldbury Quarry & 43 & O. cataractes & -27.8 & 0.8 \\
\hline MR 42406 & Oldbury Quarry & 44 & O. cataractes & -27.7 & 0.6 \\
\hline MR 42407 & Oldbury Quarry & 45 & O. cataractes & -27.5 & 0.6 \\
\hline MR 42408 & Oldbury Quarry & 46 & O. cataractes & -28.0 & 1.2 \\
\hline MR 42409 & Oldbury Quarry & 47 & O. cataractes & -27.8 & 0.6 \\
\hline
\end{tabular}

\section{FIGURE CAPTIONS}

Figure 1. Global late Cambrian palaeogeography, showing position of the Avalonia terrane with respect to major contemporary palaeocontinents (Laurentia, Baltica \& Gondwana) and ocean basins. Based on Cocks and Torsvik (2002, fig. 3).

Figure 2. Palaeogeography of England and Wales during the late Cambrian (Olenus Biozone), showing main land areas, depo-centres and areas of marine shelf deposition. Based on Map C2a in Cope et al. (1992).

Figure 3. Regional location (a), geological setting (b), and simplified geological cross section (c) of the study area. Based on Plate 12 of Taylor \& Rushton (1971).

Figure 4. Cambrian and Early Ordovician stratigraphy of the Nuneaton area, and its relationship to the Cambrian of North America.

Figure 5. Integrated stratigraphy of the Outwoods Shale Formation in the Merevale boreholes and Oldbury Quarry. Position of the Oldbury Quarry curve and section with respect to logs and signatures from the Merevale boreholes is based on the shape and magnitude of the quarry signature and regional 
geological structure. The quarry signature and section (sampled at true vertical depth) is expanded by about $13 \%$ to provide consistency with the dipping succession sampled in the boreholes.

Figure 6. The Oldbury Quarry succession [SP 30965 94922]: (a) general view showing relationship to logged section and major igneous intrusions; (b) typical Outwoods Shale Formation lithology (length of hammer ca $0.3 \mathrm{~m}$ ).

Figure 7. Global comparison of the SPICE with that recorded at Nuneaton. Correlative datum is the base of the Glyptagnostus reticulatus Biozone or its lateral equivalent. The thickness of the Nuneaton signature has been adjusted for dip. NB: the horizon of Irvingella in the Nuneaton succession is based on extrapolation of an occurrence in nearby outcrops (see Rushton, 1983, fig. 3), and appears to represent a level close to the top of its range. carb. = carbonate; org. = organic. 


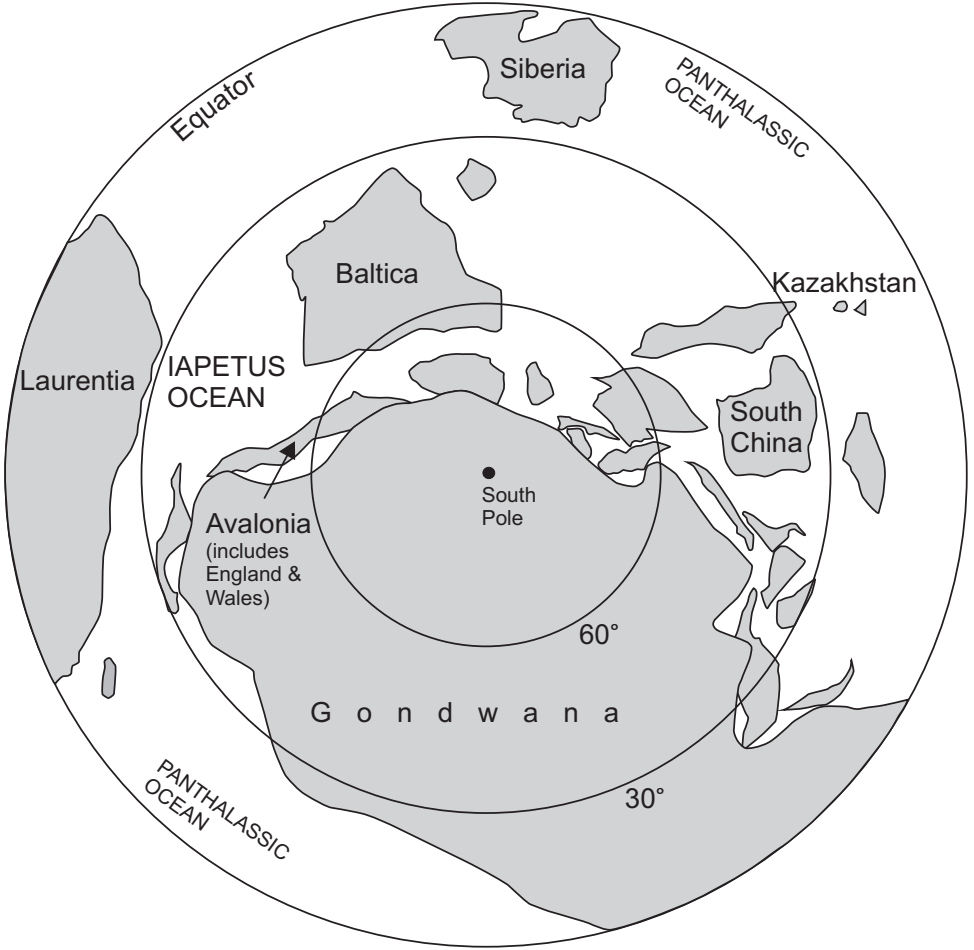

Figure 1.

Global late Cambrian palaeogeography, showing position of the Avalonia terrane with respect to major contemporary palaeocontinents (Laurentia, Baltica \& Gondwana) and ocean basins. Based on Cocks and Torsvik (2002, fig. 3). 
(a)

(b)
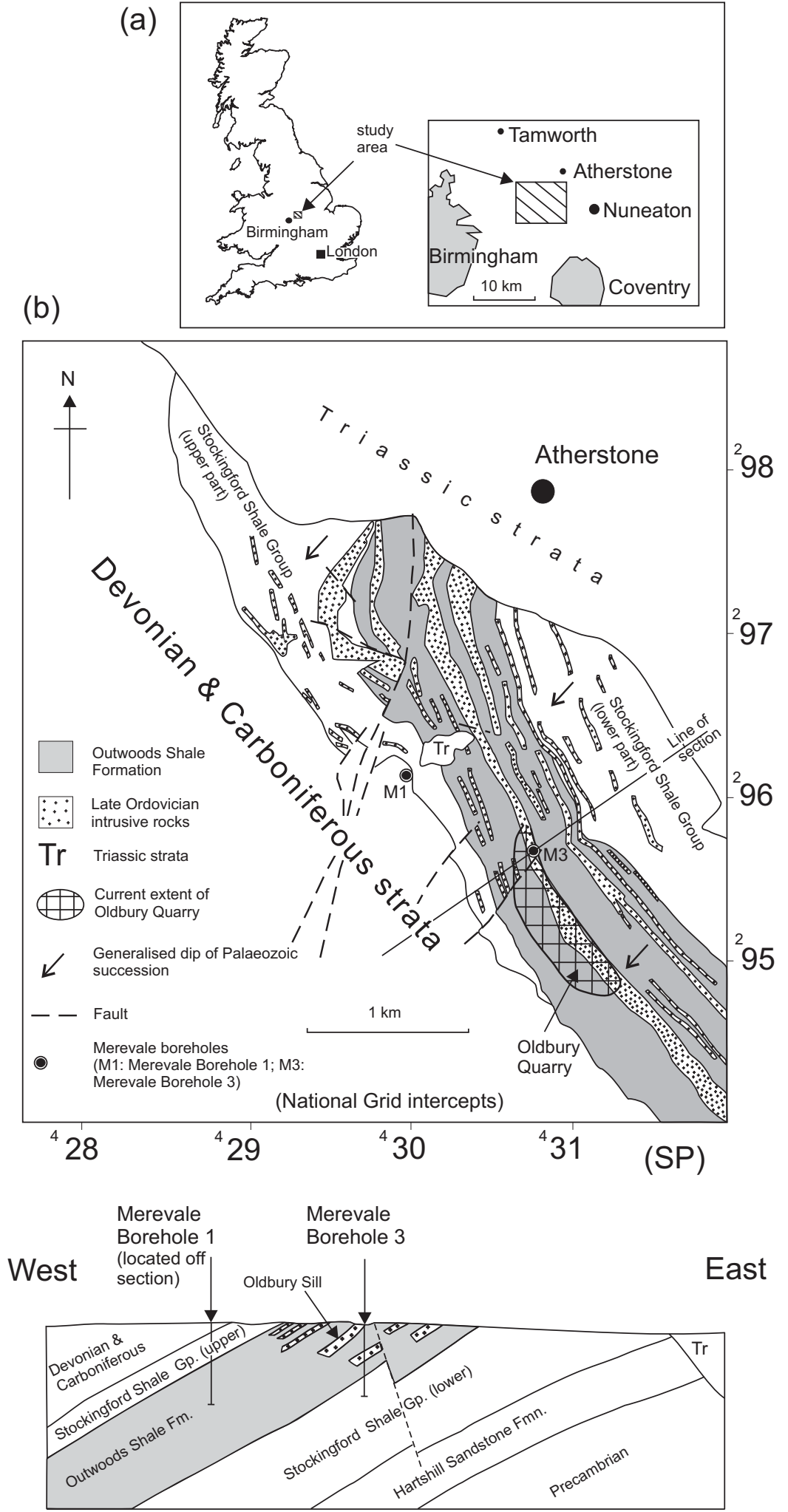

(c)

Figure 3. Regional location (a), geological setting (b), and simplified geological cross section (c) of the study area. Based on Plate 12 of Taylor \& Rushton (1971). 


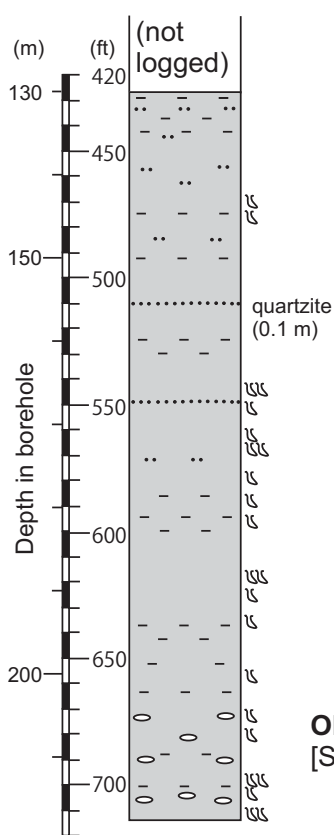

Fmn. Biozones

$\delta^{13} \mathrm{C}_{\text {(org) }}$

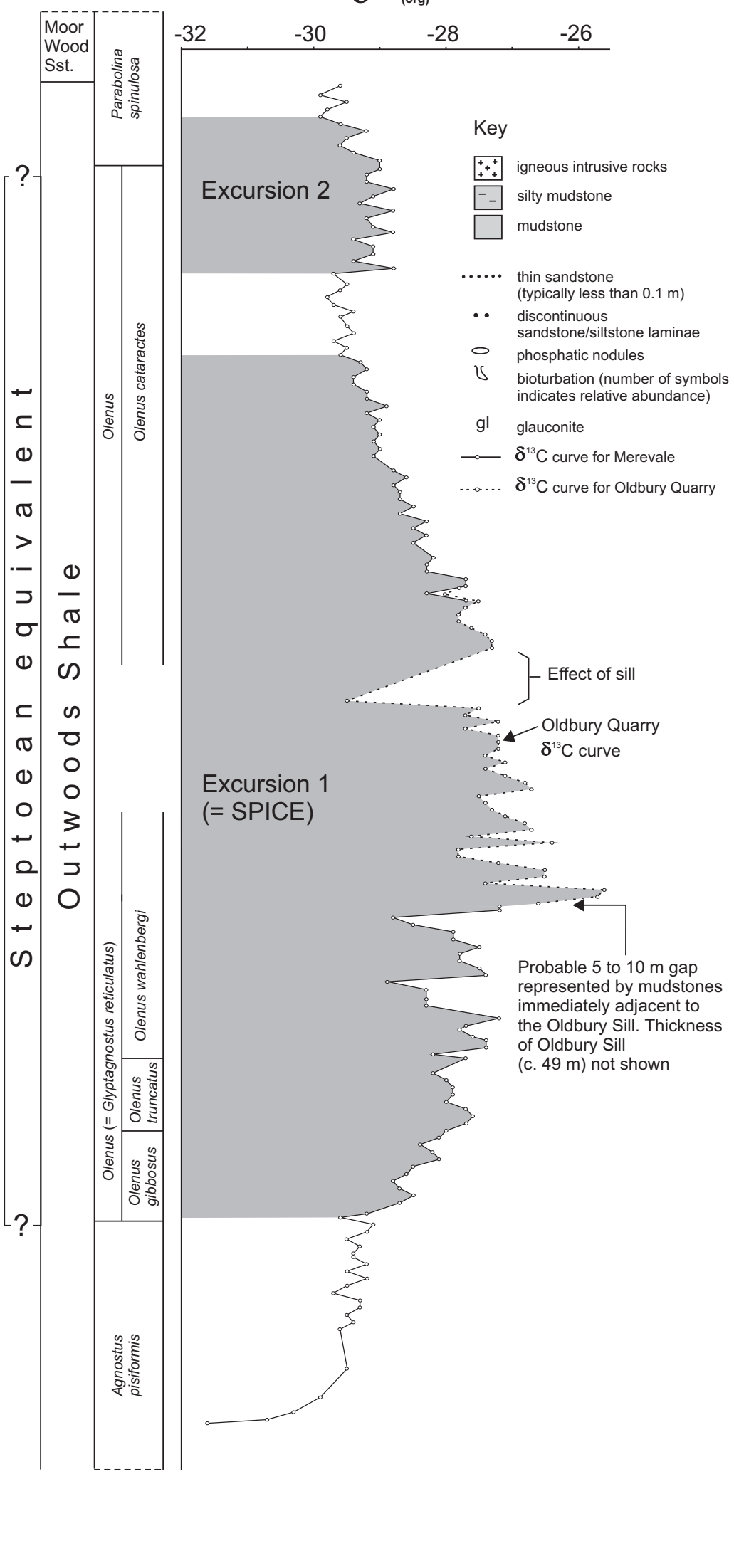

Figure 5. Integrated stratigraphy of the Outwoods Shale Formation in the Merevale boreholes and Oldbury Quarry. Position of the Oldbury Quarry curve and section with respect to logs and signatures from the Merevale boreholes is based on the shape and magnitude of the quarry signature and regional geological structure. The quarry signature and section (sampled at true vertical depth) is expanded by about $13 \%$ to provide consistency with the dipping succession sampled in the boreholes. 


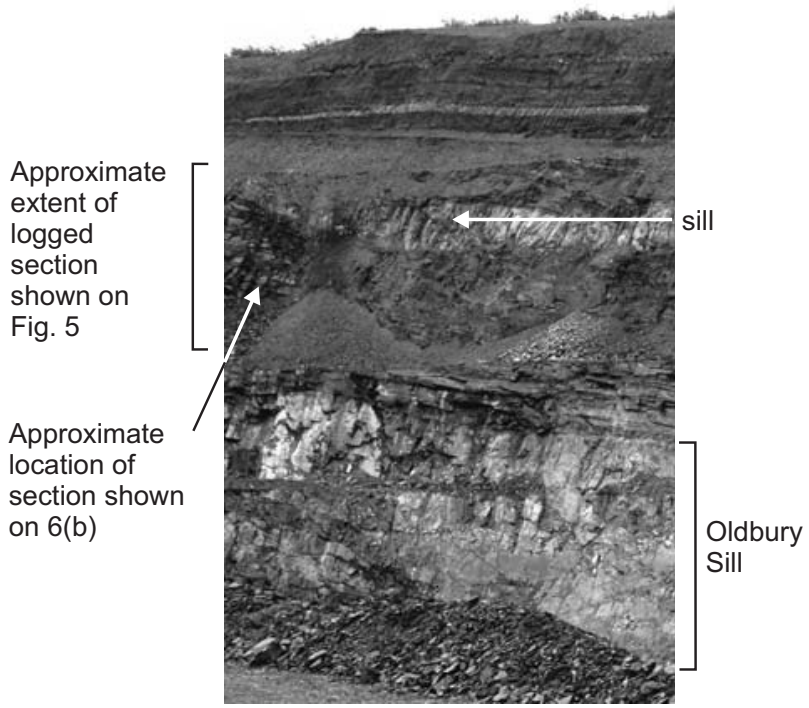

(a)

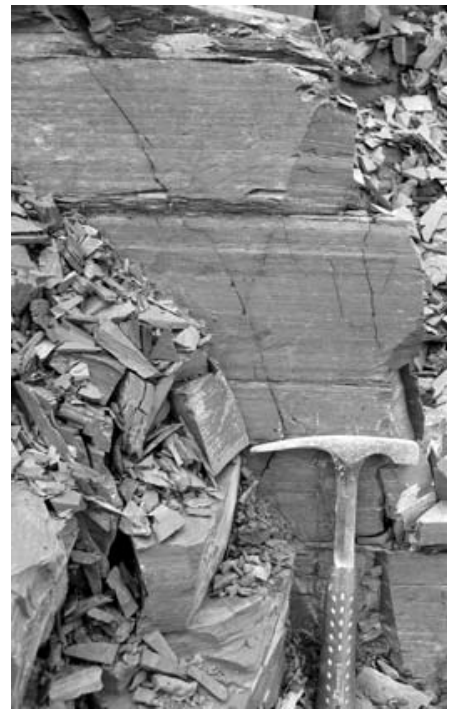

(b)

Figure 6.

The Oldbury Quarry succession [SP 30965 94922]: (a) general view showing relationship to logged section and major igneous intrusions; (b) typical Outwoods Shale Formation lithology (length of hammer ca $0.3 \mathrm{~m}$ ). 
Siberia

(Kouchinsky et al. 2008)

Peng et al., 2004)

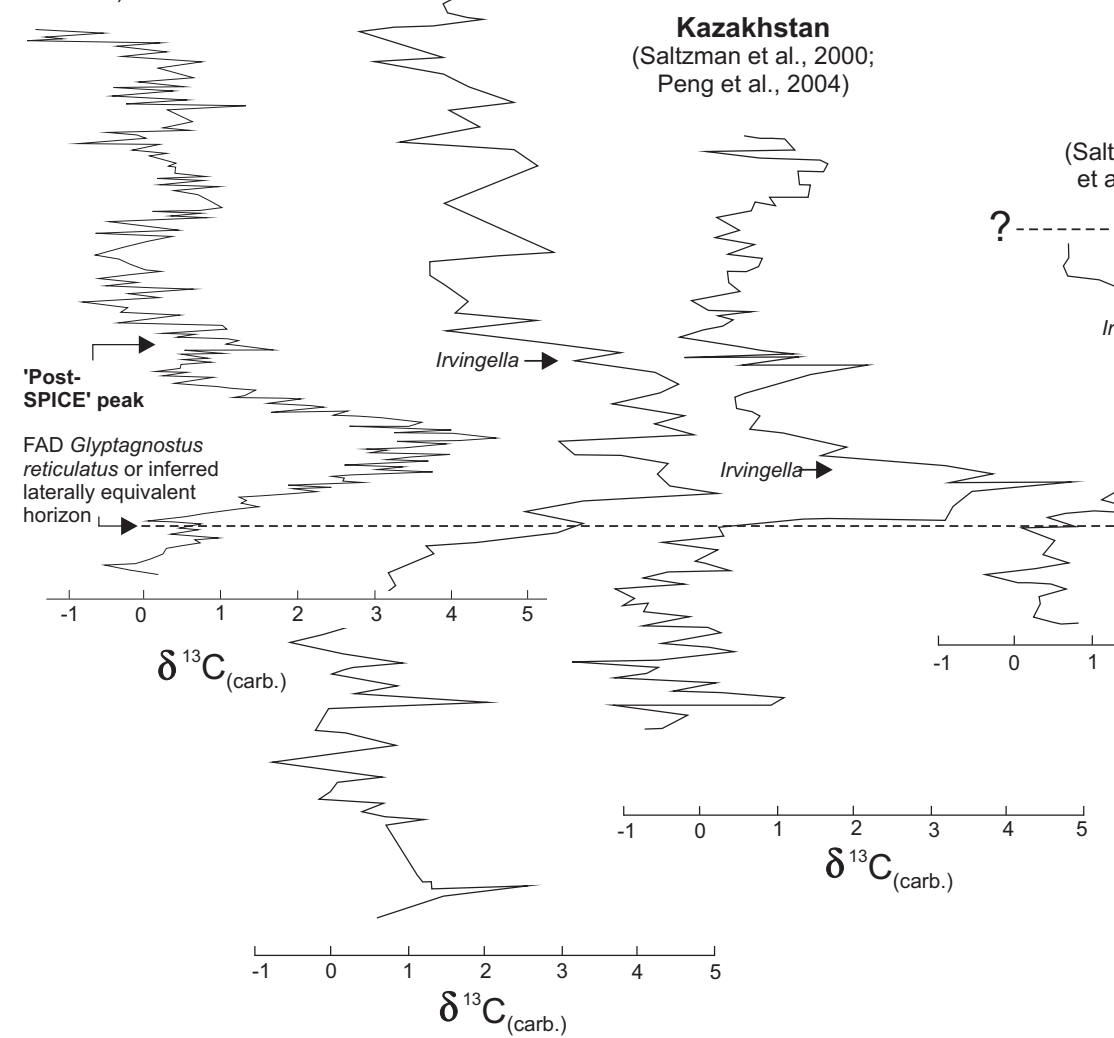

Nevada, USA

(Saltzman et al., 1998; Saltzman al., 2000; Peng et al., 2004)

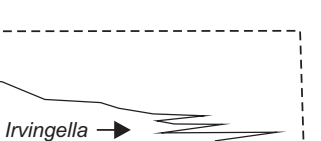

Nuneaton, UK

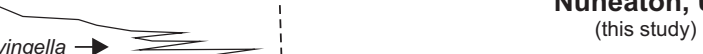
(this study)

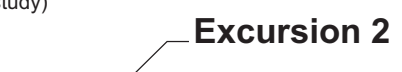
Andrarum, Sweden,
(Ahlberg et al., 2009)' Base $P$. spinulosa (Ahlberg et al., 2009, Base, . spifulosa

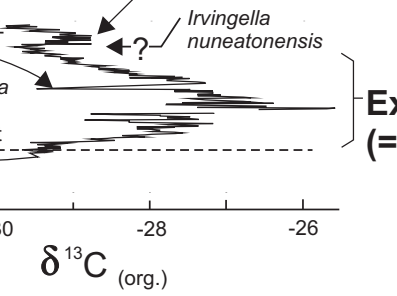

Excursion 1 (= SPICE)

Figure 7. Global comparison of the SPICE with that recorded at Nuneaton. Correlative datum is the base of the Glyptagnostus reticulatus Biozone or its lateral equivalent. The thickness of the Nuneaton signature has been adjusted for dip. NB: the horizon of Irvingella in the Nuneaton succession is based on extrapolation of an occurrence in nearby outcrops (see Rushton, 1983, fig. 3), and appears to represent a level close to the top of its range. carb. $=$ carbonate org. $=$ organic. 